distributed along the complete ellipse forming the cometary orbit. They are therefore always worth careful notice, and will seldom be found to fall below reasonable expectation.

Bristol, November 4 . W. F. Denning.

THE result of calculations made by the writer indicates that the Leonid epoch will fall a little later this year than might have been expected. There will be little, if any, meteoric activity during the period November 10-16, reckoning from noon to noon, but during the remainder of the month it is likely that shooting stars will be much in evidence. The following are the principal meteor showers that fall during the period November 16-30, the dates of the occurrences being expressed in Greenwich astronomical time :-

Epoch November 16; this shower is of the ninth order of magnitude, and has the following maxima:-November I6, IIh. 20m.; November I7, 4h. 25m., 8h. 20m., and $16 \mathrm{~h} .15 \mathrm{~m}$.

Epoch November 17, 20h., of eleventh order of magnitude. The following maxima occur after the epoch :November 18 , oh. $50 m$, Ioh.

Epoch November 2o, 5h., of fifth order of magnitude, and preceded by the following maxima:-November I8, 7 h. 5 om., 2 Ih. 5 m. ; November 19, 5 h. 55 m.; November 20 , $3 \mathrm{~h} .15 \mathrm{~m}$.

Epoch November 24, of seventh order of magnitude, which has the following maxima :-November $24,8 \mathrm{~h} .55 \mathrm{~m}$. I2h. rom.; November 25, 6h. 20m., r8h. $24 \mathrm{~m}$.

Epoch November 30 , 5 h., of fifteenth order of magnitude, and preceded by the maxima:-November 28 , 14h. 3om., 2oh. 3om.; November 29, oh. and 3h., 2oh. $45 \mathrm{~m}$.

It seems from the foregoing that the first maximum takes place on November 16 during the hour preceding midnight. This maximum, which is the only one occurring on this night, will probably furnish some Leonids, which may also be observed on the following night.

I3 1 Rathgar Road, Dublin. John R. Henry.

\section{The Keeping of Young Herring Alive in Captivity.}

ON p. 305 of the new number of the Journal of the Marine Biological Association reference is made to the difficulty of keeping young herring alive. On September 14 last I captured a number of young herring some, which I put under circulation in salt water, were dead next morning. To kill the others I turned on a fresh-water tap into the bucket containing them. Half an hour or so later I found that, instead of being dead, they were very lively, and some which had been lying on their backs had recovered.

I then placed seven under a circulation of half salt water and half fresh water. They lived for a week, then some of them died off. There is still (November 6) one lively specimen living, and apparently healthy. The only source of food is a little plankton added (twice), and such plankton as comes through the salt-water pipes.

During the first few days of this experiment sometimes the salt-water tap and at other times the fresh-water tap was shut off for an hour or so.

Richard Elmhirst.

Marine Biological Station, Millport, N.B.

\section{Lime Light.}

I VENTURE to direct your attention to a simple device which I have found very useful for increasing the light from a demonstrating lantern. It is usual, on account of their long life, to use so-called artificial lime cylinders, even though they give somewhat less light than pure lime ones. An ordinary Welsbach gas-mantle happens to fit all these cylinders, and should be slipped on before the jet is lighted. The increase in brightness of the light due to this addition is astonishing. The mantle is only slightly damaged by the jet, and by turning occasionally so that the flame impinges upon a fresh place, the intense illumination may be maintained for two hours or so.

Shooters Hill, Kent.

Charles E. S. Phillips.

\section{ALBRECHT VON HALLER.}

A LBRECHT VON HALLER, anatomist, physiologist, botanist, and poet, was born in Berne on October 16, x708. He has been termed "Berne's greatest son," and his intellectual eminence was conspicuous even in an age which was singularly productive of great men. It was, indeed, early manifest, for the child Haller was what the Germans term a "Wunderkind "- one of the few such children whose subsequent career has borne out the promise of their youth. As early as his ninth year he began the preparation of lexicons of all the Hebrew and Greek words in the Old and New Testaments, with notes regarding their derivations and different applications. He also prepared a Chaldaic grammar. Whilst still a boy he wrote biographies of no fewer than two thousand celebrities and turned out innumerable verses (which he afterwards burned) on all conceivable subjects, including a satire in Latin verse on his somewhat harsh and pedantic preceptor. Before he was fifteen he was deeply immersed in philosophy and mathematics, and already showed that inclination towards the natural sciences which eventually evidenced itself in the remarkable works which appeared from his pen.

At fifteen he entered the University of Tübingen and pursued the study of anatomy and philosophy during two years. At this time Boenhaave, a man of similar almost universal genius, then at the zenith of his fame, was attracting to Leyden earnest students from all parts of the civilised world. The youthful Haller was also drawn into the vortex, and came under the influence both of that great physician and of the anatomists Ruysch and Albinus. After graduating there at the age of nineteen, Haller visited England, and in London made the acquaintance, amongst others, of Sir Hans Sloane, Douglas, Cheselden, and John Hunter. He then proceeded to Paris, where he spent six months studying anatomy and botany under Winslow and Jussieu. After leaving Paris, he passed a year in Bâle, pursuing mathematical studies under Bernouilli, and preparing himself for the active practice of medicine in his native city, where he intended to settle down. At the age of twenty-two we accordingly find him in practice in Berne. His patients do not appear to have been numerous; indeed, it was currently reported that he was " too good a writer and poet to understand much of medicine," and he found abundance of time for working at anatomy and for expeditions to the neighbouring Alps, the flora of which especially excited his interest. The poem entitled "Die Alpen," which was composed by Haller about this time, is probably the one by which he is best known; the following two verses from it, set to music as a cantata by Dr. Munzinger, were sung at the unveiling of the Haller statue on October $16:-$

Wohl dir, vergnügtes Volk ! o danke dem Geschicke,

Das dir der Laster Quell, den Ueberfluss, versagt ;

Dem, den sein Stand vergnügt, dient Armut selbst zum Glücke,

Da Pracht und Ueppigkeit der Länder Stütze nagt.

Zwar die Natur bedeckt dein hartes Land mit Steinen,

Allein dein Pflug geht durch, und deine Saat errint

Weil sich die Menschen selbst die grössten Plagen sind.

In I735 Haller had begun to lecture in public on anatomy, and was physician to the city hospital in Berne. We also find him fulfilling the function of keeper of the public library and collection of coins. In the short year occupied with these multifarious duties he found time to prepare a "catalogue raisonne" of all the books in the library, and to differentiate and arrange in their chronological order 5000 ancient coins. In the following year George II.

No. 2037 , VOL. 79] 